\title{
Appliance Diffusion Model for Energy Efficiency Standards and Labeling Evaluation in the Capital of Lao PDR
}

\author{
Hajime Sasaki*1, Ichiro Sakata ${ }^{2}$, Weerin Wangjiraniran ${ }^{3}$, \\ Sengprasong Phrakonkham ${ }^{4}$ \\ ${ }^{1}$ Policy Alternatives Research Institute, The University of Tokyo, 7-3-1, Hongo, Bunkyo-ku, Tokyo, Japan \\ e-mail: sasaki@pari.u-tokyo.ac.jp \\ ${ }^{2}$ Policy Alternatives Research Institute, The University of Tokyo, 7-3-1, Hongo, Bunkyo-ku, Tokyo, Japan \\ e-mail: isakata@ipr-ctr.t.u-tokyo.ac.jp \\ ${ }^{3}$ Energy Research Institute, Chulalongkorn University, $12^{\text {th }}$ Floor Institute Building III, Phyathai Road, \\ Pratumwan, Bangkok, Thailand \\ e-mail: weerin@eri.chula.ac.th \\ ${ }^{4}$ Faculty of Engineering, National University of Laos, Don Noun, Vientiane, Lao PDR \\ e-mail: sengprasong@yahoo.com
}

Cite as: Sasaki, H., Sakata, I., Wangjiraniran, W., Phrakonkham, S., Appliance Diffusion Model for Energy Efficiency Standards and Labeling Evaluation in the Capital of Lao PDR, J. sustain. dev. energy water environ. syst., 3(3), pp 269-281, 2015, DOI: http://dx.doi.org/10.13044/j.sdewes.2015.03.0021

\begin{abstract}
Because of the rapid growth of energy demand in developing countries, policies for energy efficiency are receiving increasing attention. Although Energy Efficiency Standards and Labeling (EES\&L) is a standard policy tool in many countries, some developing countries, such as Lao PDR, have not yet implemented them fully. In order to understand the potential impact of EES\&L, this paper aims at collecting data that contribute to EES\&L and at analysing appliance possessions in Vientiane City, Lao PDR. We conducted an interview survey on 600 households in Vientiane City and performed logistic regression analysis that set possession of appliances as the dependent variable. As a result of the analysis, we identified that the income level and the electricity consumption are the principal independent variables and the relationship of these variables with possession rates depends on appliances. Our model helps identify appliances that are expected to be in high demand associated with either economic growth or human population increase in Vientiane City.
\end{abstract}

\section{KEYWORDS}

Energy efficiency, Standard and labeling, Minimum Energy Performance Standards (MEPS), Possession of appliances, Developing country, Regression analysis.

\section{INTRODUCTION}

The economic growth and accompanying industrialization and rising standards of living in developing countries have led to a rapid growth of energy demand. Although Energy Efficient Standards and Labeling (EES\&L) for appliances is now a standard policy tool in many countries [1], some developing countries, such as Lao People's Democratic Republic (Lao PDR), are yet to implement them fully. The country has enormous hydropower potential, but energy-efficiency economic growth would allow for more orderly development of such renewable resources.

Energy efficiency labels are assigned to appliances and they describe the energy performance of a product. These labels enable consumers to make informed purchase decisions by communicating to consumer's energy usage and costs associated with a

\footnotetext{
* Corresponding author
} 
product [2]. If implemented appropriately, the experience in various countries demonstrates that appliance standards and labels can provide concrete benefits of energy efficiency.

Another policy scheme is a Minimum Energy Performance Standard (MEPS), which literally sets the minimum required energy standard of marketed energy-consuming products. It is now widely employed in the European countries [3].

In a market with an energy-labeling program, all appliances carry an energy rating, allowing those consumers who care about the environment to choose a model that saves energy. By introducing a labeling program, policymakers can induce a market for consumers and citizens who care about the environment and wish to save energy. This mechanism is called "market pull" and increases the average efficiency of models on the market somewhat, as shown in Figure 1. In addition to the labeling system, MEPS can be introduced, which disables the sale of products of the most inefficient kind. MEPS provides a "market push," which also increases the average efficiency in the market. The two kinds of policies, energy labeling and MEPS, can be used to improve the efficiency of marketed products [4].

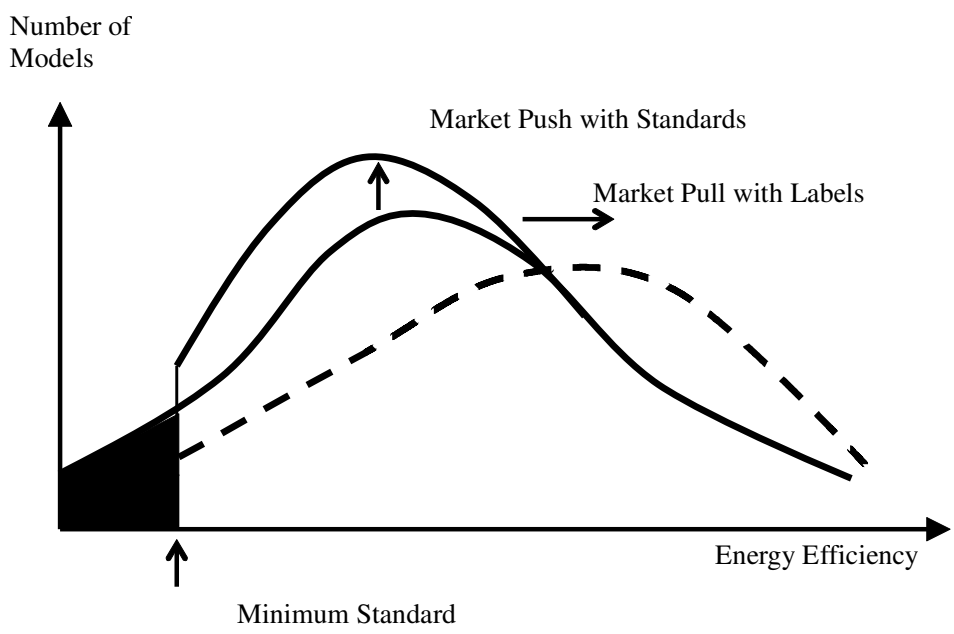

Figure 1. The effect of MEPS and labeling on the efficiency distribution of the products (Source: CLASP, 2005 [2] edited by author)

Existing research on EES\&L is mostly limited to developed and emerging economies. Rosenquist et al. [5] analysed impacts of possible improvements in energy efficiency standards for residential and commercial sectors in the US, concluding that such improvements may provide substantial benefits. Augustus de Melo and de Martino Jannuzzi [6] developed a model to assess the impacts of MEPS (particularly refrigerators) in Brazil, where the MEPS policy is in its early stage. Japan has been implementing the Top Runner Standard for various appliances, which is similar to a MEPS scheme. According to an estimate, this schemed achieved energy savings of $55.2 \%$ relative to the refrigerators shipped in 1998 [7]. Korea fervently utilized a mix of mandatory energy labeling and MEPS to improve the appliance efficiencies in the 1990s. They achieved a rather astonishing result. In a matter of 7 years, they saw a $38 \%$ improvement in the average efficiency of fluorescent lamps. Likewise, the efficiency of refrigerator-freezers is increased by $42 \%$ [8]. CLASP (Collaborative Labeling and Appliance Standards Program) explored the benefits of China's existing (as opposed to additional) standards and labeling [9]. The EES\&L programs already implemented in China are expected to lead to a cumulative saving of 1,143 TWh by 2020 . 


\section{Summary of electrification situation in Lao PDR}

Volume 3, Issue 3, pp 269-281

Lao PDR's economy is growing steadily in an increasingly sustainable way, with the reforms underway reducing poverty. Its real GDP grew by $7.1 \%$ per year on average for 2000-2010. In 2010, the Gross National Income (GNI) per capita of Lao PDR reached USD 1,040 and, the country is no longer a lower economy income country; it is now a lower-middle income economy. At the pace of current economic growth, Lao PDR's long-term vision is within reach, and it should be able to graduate from Least Developed Country status by 2020 .

Accompanying this rapid economic growth is a fast increase in energy demand in all sectors. According to the analysis by the Institute of Energy Economics of Japan, the transportation sector is expected to grow five-fold from the current level of consumption. The electricity demand has been and is also expected to rise substantially. Figure 2 shows that the average growth rate of electricity consumption for 2000-2010 is $11 \%$ [10]. Moreover, Lao PDR has been electrifying rural areas successfully (Figure 3), with an ambition to achieve an electrification rate of over $90 \%$ in 2020. This ambitious plan will be achieved by massively extending the power grid even to peripheral areas.

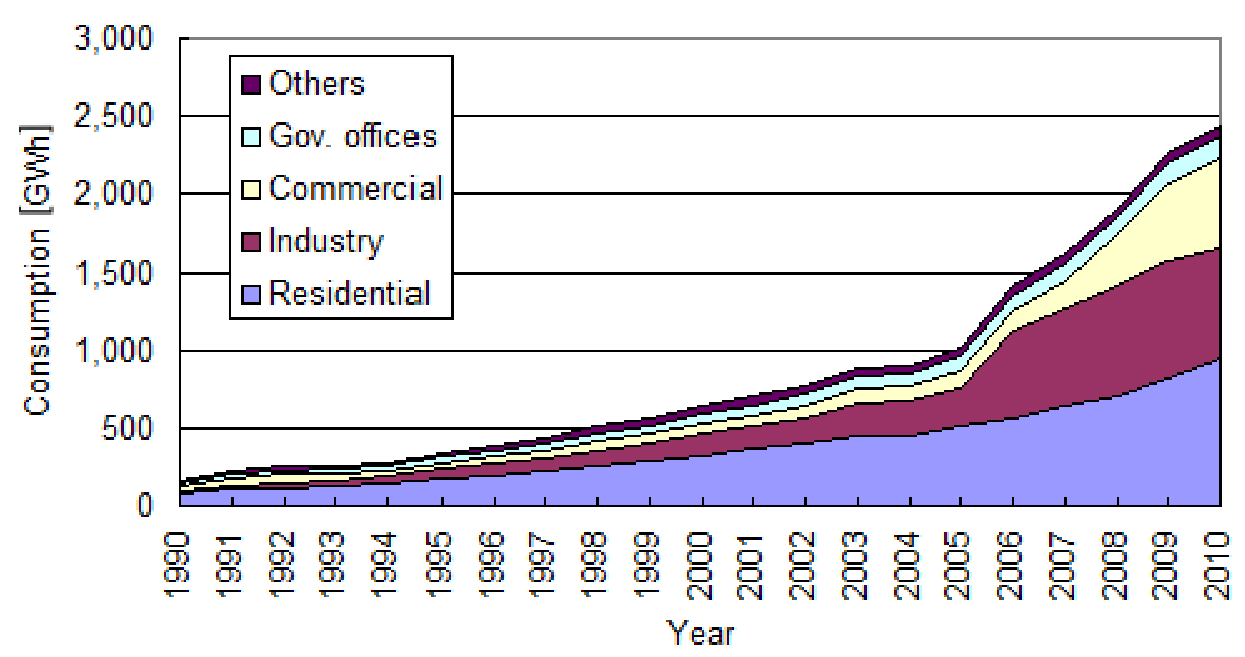

Figure 2. Total consumption of electric power

(Source: Department of Electricity, Ministry of Energy and Mines in Lao PDR, 2010 [10])

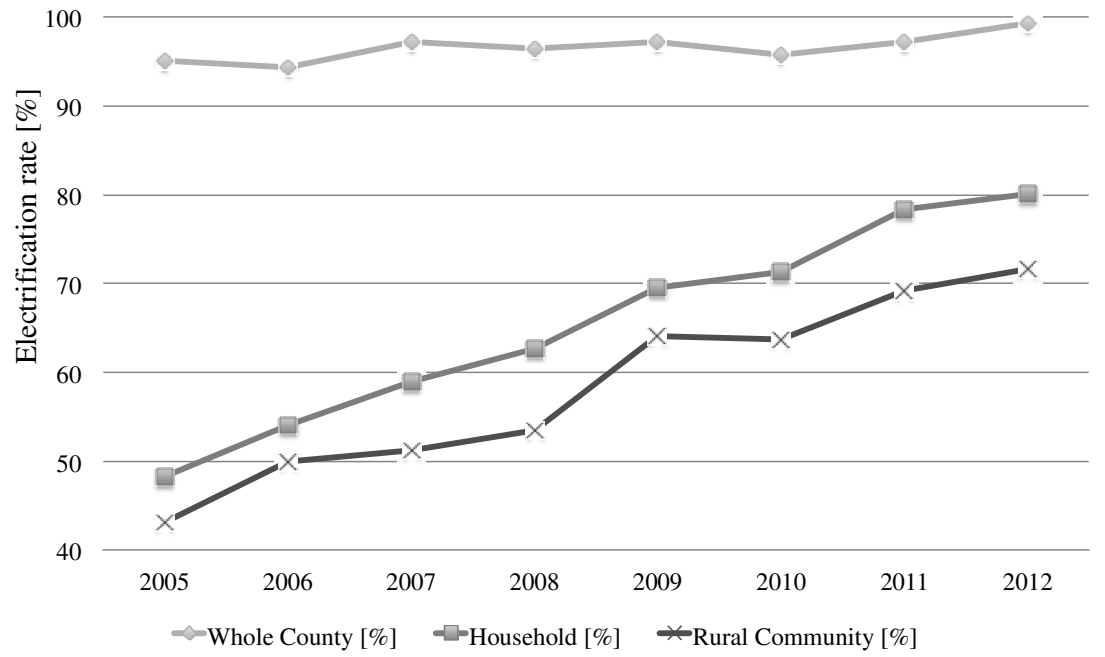

Figure 3. The electrification rate in Lao PDR 
Sasaki et al. [11] proposed a roadmap scenario of electricity technologies for Lao PDR and they conducted stakeholder meetings to foster consensus building with the Lao PDR government. However, the study emphasized the supply side over the demand efficiency. A deeper analysis from the demand perspective is urgently necessary. For instance, they will likely need to implement EES\&L in the near future, and there is a need for policy discussions on the potential EES\&L design. A model for EES\&L evaluation would be helpful to facilitate the policy design process. According to Michael et al. an econometric model of appliance diffusion serves as the basis for subsequent analyses since the future energy efficiency distribution of appliances is the starting point for assessing energy efficiency policies. Projections based on such models [12] can analyse the impact of the main drivers (wealth, urbanization, and electrification).

The purpose of this paper is to develop an econometric model of appliance diffusion that can serve as the basis for evaluation of EES\&L policies for Vientiane City, Lao PDR. As households become richer, they are expected to possess more and more appliances, with the income being a key indicator. On the other hand, different appliances should diffuse at the different levels of income, and some might even saturate early in the development stage. This motivates a model that takes into account multiple drivers associated with economic growth and socio-economic changes.

We therefore investigate which key driver contributes to the diffusion rate of each appliance in Vientiane City. Specifically, we implement a logistic regression analysis that combines income, household size and district. These results show this appliance is likely to diffuse early in the economic development allowing for priority setting in the EES\&L policy. Ideally such a regression analysis should be based on comprehensive, public statistics. Unfortunately, developing economies such as Lao PDR do not maintain data sufficient for the present purpose of demand-side analysis. We thus conducted a survey that collected the data on household possession of appliances in Vientiane City. To our knowledge, this is the first such data collection exercise. Our regression analyses are based on the collected data.

\section{METHODOLOGY}

We conducted an interview survey that mainly focused on the possession of appliances in a residential sector. In this survey, Vientiane, the capital city of Lao PDR, is set as the target area. We randomly sampled from the capital, which is divided into 5 districts and 31 villages.

The total population in Vientiane city is about 980,000 in 2013. Based on an estimation of sample size we assumed 600 households interview is enough for estimation in this city.

In this paper, we implemented a logistic regression analysis that explains the possessions of appliances as dependent variable. The appliances of our focus are refrigerators, air-conditioners, and TVs (CRT and LCD/LED), because these products are often targeted by EES\&L policies in other countries. For independent variables, we have the following:

- Income level dummy;

○ $0-2,000,000 \mathrm{kip} / \mathrm{month}$;

○ 2,000,001 - 4,000,000 kip/month;

○ 4,000,001-6,000,000 kip/month;

- $6,000,000-8,000,000 \mathrm{kip} / \mathrm{month}$;

○ 8,000,001-10,000,000 kip/month;

○ $10,000,001-12,000,000 \mathrm{kip} / \mathrm{month}$;

○ $10,000,001-14,000,000 \mathrm{kip} / \mathrm{month}$; 
○ $10,000,001-16,000,000 \mathrm{kip} / \mathrm{month}$;

○ Or 10,000,001-18,000,000 kip/month.

The number of males, the number of females, monthly consumption of electricity $\mathrm{kWh} /$ month, type of house dummy (concrete, wooden or mixed) and district dummy (Hadsaifong district, Saysettha district, Sikhotabong district or Sisatthanak district).

\section{RESULTS}

\section{Summary of the data}

By two-stage random sampling, we approached 600 households in Vientiane City, and obtained 577 responses. Figure 4 shows a histogram of the monthly household income answered by 577 subjects. The modal class is 2,000,000 kip (260 USD)/month 4,000,000 kip (520 USD)/month and accounts for 40\% of the total. So we can assume that this demographic class is the middle-income bracket in Vientiane City. Similarly, Figures 5 and 6 describe histograms of the monthly consumption of electricity $\mathrm{kWh} /$ month and the monthly average electricity cost kip/month, respectively. Most respondents are using below $500 \mathrm{kWh} /$ month. On the other hand, some households exceed $3,000 \mathrm{kWh} /$ month. As there is a strong correlation between the monthly consumption of electricity and the monthly average electricity cost (Adjusted $R$-squared: 0.82 ), we cannot use both of them as independent variables; otherwise, we would face a problem of multicollinearity in the regression analysis. In the following, we select the monthly consumption of electricity as an independent variable.

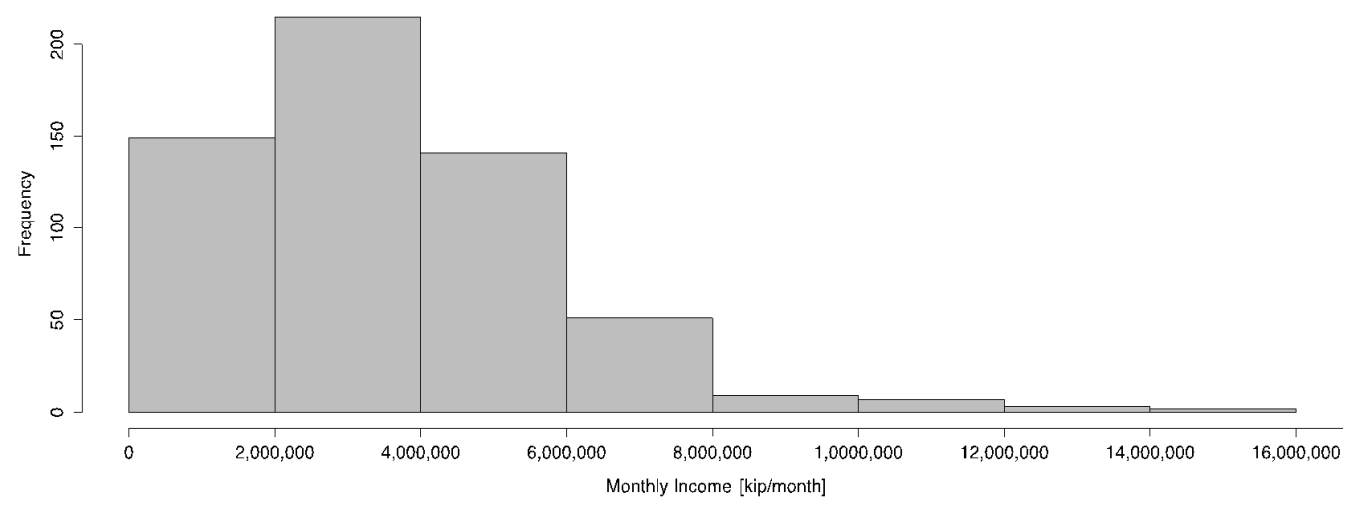

Figure 4. Histogram of monthly income [kip/month]

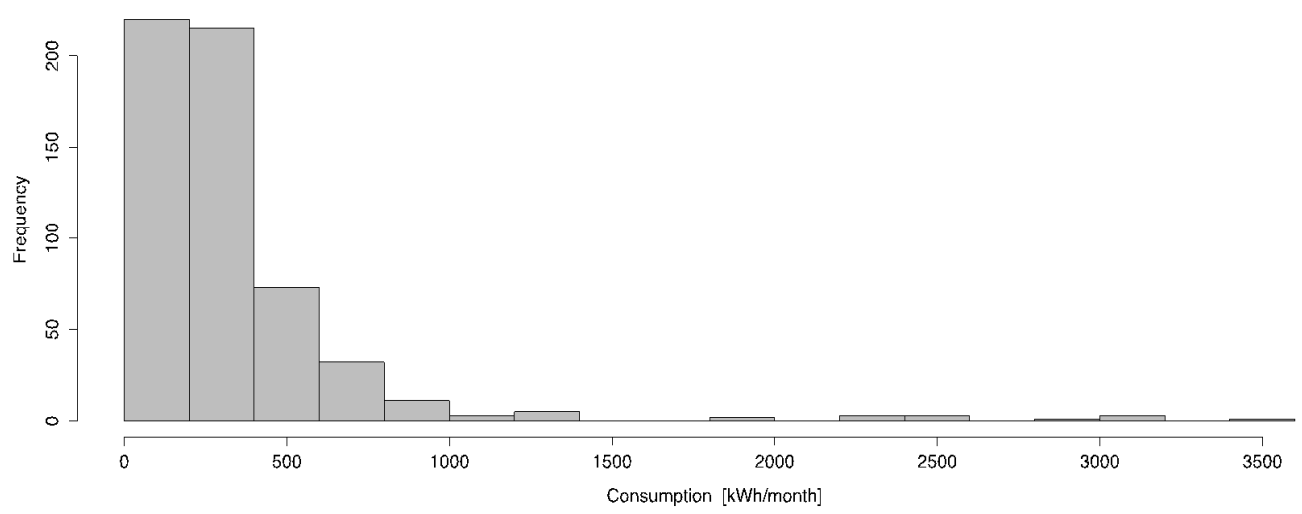

Figure 5. Histogram of monthly consumption of electricity [kWh/month] 


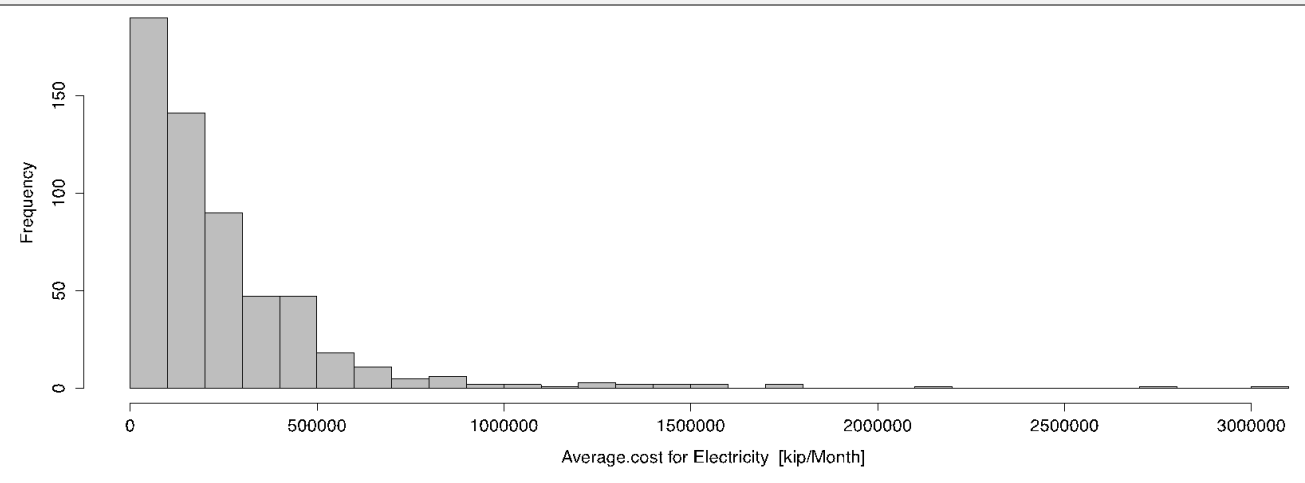

Figure 6. Histogram of monthly average electricity cost [kip/month]

Figure 7 shows the number of households that possess each appliance (by the bar chart with left axis) and the average number of units of each appliance in each household (by the line chart with right axis). As can be seen from the bar chart with the left axis, there are very few households that do not have mobile phones (household diffusion rate of 98\%). According to "World Telecommunication/ICT Indicators Database, June 2012", the diffusion rate of mobile phones was $87.2 \%$ in the whole of Lao PDR in 2011. For other appliances, the diffusion rates are as follows:

- Refrigerators 94\%;

- Air conditioners (Split wall type) 50\%;

- Air conditioners (Split floor type) 7\%;

- TVs (CRT) 83\%;

- TVs (LCD/LED) 38\%;

- CFLs 5\%,

- Vacuum machines 5\%;

- PCs $17 \%$;

- Microwaves $25 \%$.

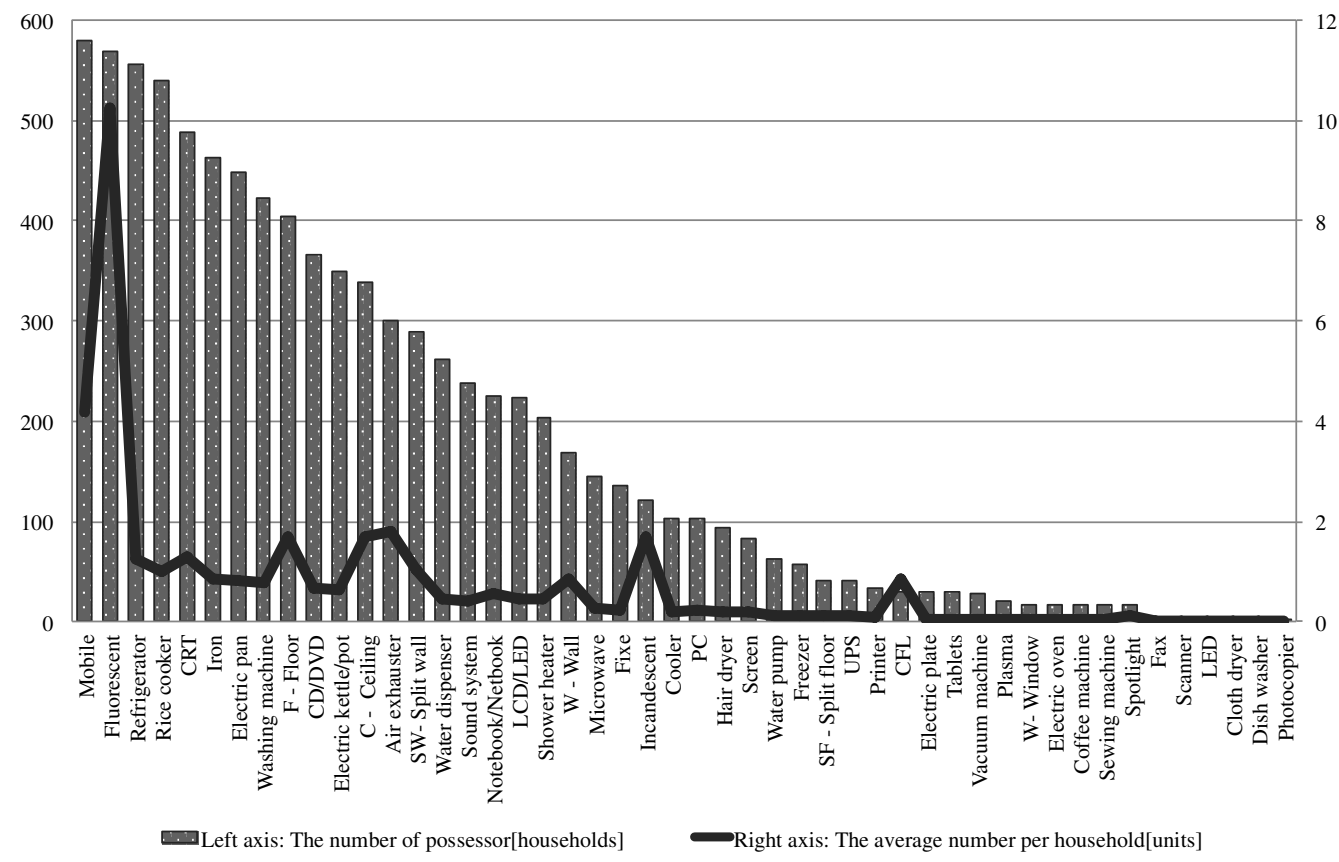

Figure 7. The number of possessors (households), (left axis: bar chart); and the average number in households (units), (right axis: line chart) 
On the other hand, the line chart with right axis shows the number obtained from the total number of ownership respondents of each appliance divided by the number of respondents from 577 households. For example, the average number of units of fluorescent lamps in each household is 10 units. In contrast, the average number of units of mobile phones is 4 .

\section{Regression analysis}

Based on these data we conducted logistic regression in which the dependent variable is possession (binary data) of:

- Refrigerators;

- Air-conditioners (Split wall type and Split floor type),

- TVs (CRT type and LCD/LED type);

- CFLs;

- Vacuum machines;

- PCs;

- Microwaves.

Table 1 indicates the result of logistic regression analysis in which the dependent variable is possession of a refrigerator. The significant contribution of income level to possession of a refrigerator is mentioned in the Bottom-Up Energy Analysis System model (BUENAS model) as EES\&L forecasting model [1]. From our result, any independent variables do not contribute to possession of refrigerators. Because the diffusion rate of refrigerators in this city is $94 \%$ as explained in Figure 7 , it is quite natural that it should be so and we can understand that refrigerators are universally distributed regardless of income level, the size and type of family and geo-location.

Table 1. The result for refrigerators

\begin{tabular}{|c|c|c|c|c|}
\hline & Estimate & Std. error & $z$ value & $\operatorname{Pr}(>|z|)$ \\
\hline (Intercept) & $1.72 \mathrm{E}+01$ & $3.96 \mathrm{E}+03$ & 0.004 & 0.997 \\
\hline Monthly income & 8.58E-02 & $1.32 \mathrm{E}-01$ & 0.651 & 0.515 \\
\hline The number of male & 8.72E-02 & $1.52 \mathrm{E}-01$ & 0.574 & 0.566 \\
\hline The number of female & 7.14E-02 & $1.37 \mathrm{E}-01$ & 0.52 & 0.603 \\
\hline Electric consumption & 2.05E-04 & $5.51 \mathrm{E}-04$ & 0.371 & 0.71 \\
\hline Concrete house & $-1.50 \mathrm{E}+01$ & $3.96 \mathrm{E}+03$ & -0.004 & 0.997 \\
\hline Wooden house & $-9.53 \mathrm{E}-02$ & $4.04 \mathrm{E}+03$ & 0 & 1 \\
\hline Mixed house & $-1.49 \mathrm{E}+01$ & $3.96 \mathrm{E}+03$ & -0.004 & 0.997 \\
\hline Hadsaifong district & $5.32 \mathrm{E}-01$ & $6.68 \mathrm{E}-01$ & 0.798 & 0.425 \\
\hline Saysettha district & $-3.72 \mathrm{E}-01$ & $5.55 \mathrm{E}-01$ & -0.671 & 0.502 \\
\hline Sikhotabong district & 3.33E-01 & $6.23 \mathrm{E}-01$ & 0.541 & 0.588 \\
\hline Sisatthanak district & $-2.93 \mathrm{E}-01$ & $5.84 \mathrm{E}-01$ & -0.502 & 0.615 \\
\hline
\end{tabular}

Table 2 indicates the result of analysis in which the dependent variable is possession of air-conditioners (Split wall type). Table 3 shows the result of analysis in which the dependent variable is possession of air-conditioners (Split floor type). From the Table 2 , we can see that the monthly income level and electricity consumption contribute significantly $(P<0.001)$. We should interpret that there is causality between the 
possession of air-conditioner and the monthly income and electricity consumption. It is implicit that the households that use air-conditioners (Split wall type) consume a large amount of electricity. It is interesting that the variable of "Sisatthanak district" strongly contributes to the possession of air-conditioners (Split wall type), meaning that this type of air conditioners is highly distributed in this district. On the other hand, from the Table 3 , we can figure out that any independent variables do not contribute to the possession of air-conditioners (Split wall type) without "Saysettha district" variable. From this result, the diffusion of the type of air conditioners depends on the district in Vientiane city.

Table 2. The result of air-conditioners (Split wall type)

\begin{tabular}{|c|c|c|c|c|}
\hline & Estimate & Std. error & $z$ value & $\operatorname{Pr}(>|z|)$ \\
\hline (Intercept) & $-1.46 \mathrm{E}+01$ & $5.35 \mathrm{E}+02$ & -0.027 & 0.9782 \\
\hline Monthly income & 3.72E-01 & $7.41 \mathrm{E}-02$ & 5.017 & $5.26 \mathrm{E}-07^{* * * *}$ \\
\hline The number of male & $6.31 \mathrm{E}-02$ & $7.42 \mathrm{E}-02$ & 0.85 & 0.3955 \\
\hline The number of female & $9.62 \mathrm{E}-03$ & $6.07 \mathrm{E}-02$ & 0.158 & 0.8742 \\
\hline Electric consumption & $3.23 \mathrm{E}-03$ & $5.63 \mathrm{E}-04$ & 5.739 & $9.50 \mathrm{E}-09^{* * *}$ \\
\hline Concrete house & $1.29 \mathrm{E}+01$ & $5.35 \mathrm{E}+02$ & 0.024 & 0.9808 \\
\hline Wooden house & $1.25 \mathrm{E}+01$ & $5.35 \mathrm{E}+02$ & 0.023 & 0.9813 \\
\hline Mixed house & $1.27 \mathrm{E}+01$ & $5.35 \mathrm{E}+02$ & 0.024 & 0.9811 \\
\hline Hadsaifong district & $8.42 \mathrm{E}-02$ & $3.04 \mathrm{E}-01$ & 0.277 & 0.7814 \\
\hline Saysettha district & $5.02 \mathrm{E}-02$ & $2.96 \mathrm{E}-01$ & 0.17 & 0.8652 \\
\hline Sikhotabong district & $-2.87 \mathrm{E}-01$ & $2.93 \mathrm{E}-01$ & -0.98 & 0.3269 \\
\hline Sisatthanak district & $-6.49 \mathrm{E}-01$ & $3.18 \mathrm{E}-01$ & -2.037 & $0.0417^{*}$ \\
\hline
\end{tabular}

Table 3. The result of air-conditioners (Split floor type)

\begin{tabular}{ccccc}
\hline & Estimate & Std. error & $z$ value & $\operatorname{Pr}(>|z|)$ \\
\hline (Intercept) & $-1.46 \mathrm{E}+01$ & $8.83 \mathrm{E}+02$ & -0.017 & 0.9868 \\
Monthly income & $9.46 \mathrm{E}-02$ & $1.15 \mathrm{E}-01$ & 0.823 & 0.4105 \\
The number of male & $-1.13 \mathrm{E}-02$ & $1.41 \mathrm{E}-01$ & -0.08 & 0.9361 \\
The number of female & $-1.42 \mathrm{E}-01$ & $1.32 \mathrm{E}-01$ & -1.078 & 0.2808 \\
Electric consumption & $6.95 \mathrm{E}-04$ & $4.29 \mathrm{E}-04$ & 1.618 & 0.1056 \\
Concrete house & $1.24 \mathrm{E}+01$ & $8.83 \mathrm{E}+02$ & 0.014 & 0.9888 \\
Wooden house & $1.28 \mathrm{E}+01$ & $8.83 \mathrm{E}+02$ & 0.015 & 0.9884 \\
Mixed house & $1.25 \mathrm{E}+01$ & $8.83 \mathrm{E}+02$ & 0.014 & 0.9887 \\
Hadsaifong district & $-5.47 \mathrm{E}-01$ & $5.18 \mathrm{E}-01$ & -1.057 & 0.2904 \\
Saysettha district & $-2.97 \mathrm{E}+00$ & $1.09 \mathrm{E}+00$ & -2.732 & $0.0063^{* *}$ \\
Sikhotabong district & $-6.11 \mathrm{E}-01$ & $5.15 \mathrm{E}-01$ & -1.185 & 0.2359 \\
Sisatthanak district & $6.59 \mathrm{E}-02$ & $4.72 \mathrm{E}-01$ & 0.139 & 0.8891 \\
\hline --- Signif. Codes: 0 ‘***’ 0.001 ‘**’ 0.01 '*’ 0.05 ‘’ $0.1{ }^{` *} 1$ & &
\end{tabular}

Table 4 indicates the result of analysis in which the dependent variable is possession of TV (CRT). Table 5 indicates the result of analysis in which the dependent variable is possession of a TVs (LCD/LED). The possession of TVs (CRT) is highly contributed by some variables; the monthly income $(P<0.1)$, the number of women in the household 
$(P<0.05)$, electric consumption $(P<0.1)$, Sikhotabong district $(P<0.01)$ and Sisatthanak district $(P<0.05)$. Since the diffusion rate of TVs $(\mathrm{CRT})$ is $83 \%$, it is estimated that the appliances have already been widely diffused to the public. According to the Table 5, significant variables of possession of TVs (LCD/LED) are monthly income $(P<0.001)$, electric consumption $(P<0.001)$ and Sikhotabong district $(P<0.01)$. The number of households that possess an LCD/LED is 223 and the diffusion rate of LCD/LED is $38 \%$. In general, LCD/LED-TVs belong to the expensive category in televisions, so it is reasonable that income level contributes significantly.

Table 4. The result of TVs (CRT)

\begin{tabular}{ccccc}
\hline & Estimate & Std. error & $z$ value & $\operatorname{Pr}(>|z|)$ \\
\hline (Intercept) & $1.24 \mathrm{E}+01$ & $5.35 \mathrm{E}+02$ & 0.023 & 0.9815 \\
Monthly income & $-1.42 \mathrm{E}-01$ & $7.68 \mathrm{E}-02$ & -1.843 & 0.06528 \\
The number of male & $3.88 \mathrm{E}-02$ & $9.30 \mathrm{E}-02$ & 0.417 & 0.67653 \\
The number of female & $2.29 \mathrm{E}-01$ & $9.42 \mathrm{E}-02$ & 2.435 & $0.0149^{*}$ \\
Electric consumption & $-4.57 \mathrm{E}-04$ & $2.61 \mathrm{E}-04$ & -1.749 & 0.08022 \\
Concrete house & $-1.17 \mathrm{E}+01$ & $5.35 \mathrm{E}+02$ & -0.022 & 0.98263 \\
Wooden house & $-1.04 \mathrm{E}+01$ & $5.35 \mathrm{E}+02$ & -0.019 & 0.98452 \\
Mixed house & $-1.18 \mathrm{E}+01$ & $5.35 \mathrm{E}+02$ & -0.022 & 0.98249 \\
Hadsaifong district & $5.21 \mathrm{E}-01$ & $3.41 \mathrm{E}-01$ & 1.526 & 0.127 \\
Saysettha district & $5.39 \mathrm{E}-01$ & $3.31 \mathrm{E}-01$ & 1.631 & 0.10296 \\
Sikhotabong district & $0.65 \mathrm{E}-01$ & $3.68 \mathrm{E}-01$ & 2.624 & $0.00869^{* *}$ \\
Sisatthanak district & $9.19 \mathrm{E}-01$ & $3.91 \mathrm{E}-01$ & 2.349 & $0.01883^{*}$ \\
\hline
\end{tabular}

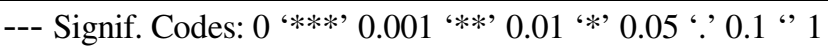

Table 5. The result of TVs (LCD/LED)

\begin{tabular}{|c|c|c|c|c|}
\hline & Estimate & Std. error & $z$ value & $\operatorname{Pr}(>|z|)$ \\
\hline (Intercept) & $-1.40 \mathrm{E}+01$ & $5.35 \mathrm{E}+02$ & -0.026 & 0.9791 \\
\hline Monthly income & $2.42 \mathrm{E}-01$ & $6.65 \mathrm{E}-02$ & 3.643 & $0.00027^{* * *}$ \\
\hline The number of male & $3.43 \mathrm{E}-02$ & $7.36 \mathrm{E}-02$ & 0.464 & 0.64249 \\
\hline The number of female & $-6.71 E-02$ & $6.41 \mathrm{E}-02$ & -1.048 & 0.29482 \\
\hline Electric consumption & $1.42 \mathrm{E}-03$ & $3.51 \mathrm{E}-04$ & 4.047 & $5.19 \mathrm{E}-05^{* * *}$ \\
\hline Concrete house & $1.31 \mathrm{E}+01$ & $5.35 \mathrm{E}+02$ & 0.024 & 0.98046 \\
\hline Wooden house & $1.09 \mathrm{E}+01$ & $5.35 \mathrm{E}+02$ & 0.02 & 0.98376 \\
\hline Mixed house & $1.28 \mathrm{E}+01$ & $5.35 \mathrm{E}+02$ & 0.024 & 0.98094 \\
\hline Hadsaifong district & $-2.53 \mathrm{E}-01$ & $2.93 \mathrm{E}-01$ & -0.862 & 0.38857 \\
\hline Saysettha district & $-4.17 E-01$ & $2.87 \mathrm{E}-01$ & -1.451 & 0.1467 \\
\hline Sikhotabong district & $-9.18 \mathrm{E}-01$ & $3.04 \mathrm{E}-01$ & -3.018 & $0.00255^{* *}$ \\
\hline Sisatthanak district & $-3.36 \mathrm{E}-01$ & $3.05 \mathrm{E}-01$ & -1.101 & 0.2708 \\
\hline
\end{tabular}

Table 6 explains that monthly income contributes for the possessions of CFLs. CFLs are well-known appliances for EES\&L in other countries. CFLs are energy efficient but high-price appliances. Then, it is no wonder that the monthly income contributes for the possessions. It is interesting that the number of women in the household also contributes 
to the possession. Another interesting fact about the diffusion of CFLs is that s appliances are obviously distributed in Saysettha district than other districts: Hadsaifong, Sikhotabong and Sisatthanak. It is to be noted that our analysis does not model the number of each appliance in the households but possession (yes or no) of each appliance.

Table 6. The result of CFLs

\begin{tabular}{|c|c|c|c|c|}
\hline & Estimate & Std. error & $z$ value & $\operatorname{Pr}(>|z|)$ \\
\hline (Intercept) & $-1.43 \mathrm{E}+01$ & $8.83 \mathrm{E}+02$ & -0.016 & 0.987 \\
\hline Monthly income & $-3.24 \mathrm{E}-01$ & $1.46 \mathrm{E}-01$ & -2.222 & $0.0263^{*}$ \\
\hline The number of male & $2.21 \mathrm{E}-01$ & $1.55 \mathrm{E}-01$ & 0.142 & 0.8868 \\
\hline The number of female & $1.84 \mathrm{E}-01$ & $8.87 \mathrm{E}-02$ & 2.071 & $0.0384^{*}$ \\
\hline Electric consumption & $3.27 \mathrm{E}-04$ & $3.51 \mathrm{E}-04$ & 0.934 & 0.3504 \\
\hline Concrete house & $1.07 \mathrm{E}+01$ & $8.83 \mathrm{E}+02$ & 0.012 & 0.9903 \\
\hline Wooden house & $1.07 \mathrm{E}+01$ & $8.83 \mathrm{E}+02$ & 0.012 & 0.9904 \\
\hline Mixed house & $1.04 \mathrm{E}+01$ & $8.83 \mathrm{E}+02$ & 0.012 & 0.9906 \\
\hline Hadsaifong district & $-4.16 \mathrm{E}-01$ & $9.34 \mathrm{E}-01$ & -0.446 & 0.6559 \\
\hline Saysettha district & $1.63 \mathrm{E}+00$ & $6.80 \mathrm{E}-01$ & 2.398 & $0.0165^{*}$ \\
\hline Sikhotabong district & $-2.98 \mathrm{E}-01$ & $8.52 \mathrm{E}-01$ & -0.349 & 0.7269 \\
\hline Sisatthanak district & $-1.11 \mathrm{E}-01$ & $8.46 \mathrm{E}-01$ & -0.131 & 0.8961 \\
\hline
\end{tabular}

It is difficult to say that monthly income contributes to the possession of vacuum machines, according to the result of analysis as shown in Table 7. On the other hand, the electric consumption contributes strongly to possession. This appliance is widely spread in Hadsaifong district.

Table 7. The result of vacuum machines

\begin{tabular}{|c|c|c|c|c|}
\hline & Estimate & Std. error & $\mathrm{z}$ value & $\operatorname{Pr}(>|z|)$ \\
\hline (Intercept) & $-1.89 \mathrm{E}+01$ & $1.08 \mathrm{E}+04$ & -0.002 & 0.9986 \\
\hline Monthly income & $-1.49 \mathrm{E}-01$ & $1.33 \mathrm{E}-01$ & -1.126 & 0.2602 \\
\hline The number of male & $8.45 \mathrm{E}-03$ & $1.66 \mathrm{E}-01$ & 0.051 & 0.9595 \\
\hline The number of female & $-1.04 \mathrm{E}-01$ & $1.52 \mathrm{E}-01$ & -0.687 & 0.4919 \\
\hline Electric consumption & $1.61 \mathrm{E}-03$ & $3.45 \mathrm{E}-04$ & $4.672^{* * *}$ & $2.99 \mathrm{E}-06$ \\
\hline Concrete house & $1.67 \mathrm{E}+01$ & $1.08 \mathrm{E}+04$ & 0.002 & 0.9988 \\
\hline Wooden house & 7.96E-02 & $1.10 \mathrm{E}+04$ & 0 & 1 \\
\hline Mixed house & $1.02 \mathrm{E}-01$ & $1.08 \mathrm{E}+04$ & 0 & 1 \\
\hline Hadsaifong district & $-3.04 \mathrm{E}+00$ & $1.27 \mathrm{E}+00$ & -2.396 & $0.0166^{*}$ \\
\hline Saysettha district & $-8.49 \mathrm{E}-01$ & $6.21 \mathrm{E}-01$ & -1.368 & 0.1713 \\
\hline Sikhotabong district & $-7.76 \mathrm{E}-01$ & $6.51 \mathrm{E}-01$ & -1.192 & 0.2334 \\
\hline Sisatthanak district & $-5.26 \mathrm{E}-01$ & $6.20 \mathrm{E}-01$ & -0.849 & 0.3961 \\
\hline
\end{tabular}

Table 8 shows the result of analysis about possession of PCs. This result of PCs is similar with the result for vacuum machines. In both of them, electric consumption contributes strongly but monthly income does not. From this result we can estimate that 
these appliances are high-consumption electric appliances. We can also assume that PCs may be left turned on the whole day in some households.

Table 8. The result of PCs

\begin{tabular}{|c|c|c|c|c|}
\hline & Estimate & Std. error & $z$ value & $\operatorname{Pr}(>|z|)$ \\
\hline (Intercept) & $-1.42 \mathrm{E}+01$ & $5.35 \mathrm{E}+02$ & -0.026 & 0.97889 \\
\hline Monthly income & $6.13 \mathrm{E}-02$ & $7.53 \mathrm{E}-02$ & 0.815 & 0.41529 \\
\hline The number of male & $1.31 \mathrm{E}-01$ & $8.51 \mathrm{E}-02$ & 1.542 & 0.12315 \\
\hline The number of female & $4.75 \mathrm{E}-02$ & $6.42 \mathrm{E}-02$ & 0.74 & 0.45931 \\
\hline Electric consumption & $6.57 \mathrm{E}-04$ & $2.47 \mathrm{E}-04$ & $2.664^{* *}$ & 0.00772 \\
\hline Concrete house & $1.20 \mathrm{E}+01$ & $5.35 \mathrm{E}+02$ & 0.022 & 0.98208 \\
\hline Wooden house & $1.13 \mathrm{E}+01$ & $5.35 \mathrm{E}+02$ & 0.021 & 0.98319 \\
\hline Mixed house & $1.17 \mathrm{E}+02$ & $5.35 \mathrm{E}+02$ & 0.022 & 0.98264 \\
\hline Hadsaifong district & $-7.11 \mathrm{E}-01$ & $4.02 \mathrm{E}-01$ & -1.767 & 0.07715 \\
\hline Saysettha district & $-5.63 \mathrm{E}-01$ & $3.72 \mathrm{E}-01$ & -1.514 & 0.13014 \\
\hline Sikhotabong district & $2.18 \mathrm{E}-01$ & $3.40 \mathrm{E}-01$ & 0.64 & 0.52189 \\
\hline Sisatthanak district & $-2.89 \mathrm{E}-01$ & $3.81 \mathrm{E}-01$ & -0.758 & 0.4485 \\
\hline
\end{tabular}

From the Table 9, we can understand that the microwave is a luxury item for Vientiane's citizens. The analysis also reflects that this electric appliance is a high-consuming one.

Table 9. The result of microwaves

\begin{tabular}{|c|c|c|c|c|}
\hline & Estimate & Std. error & $z$ value & $\operatorname{Pr}(>|z|)$ \\
\hline (Intercept) & $-1.43 \mathrm{E}+01$ & $5.35 \mathrm{E}+02$ & -0.027 & 0.9787 \\
\hline Monthly income & $1.78 \mathrm{E}-01$ & 7.22E-02 & 2.461 & $0.0139^{*}$ \\
\hline The number of male & $-1.80 \mathrm{E}-02$ & 8.34E-02 & -0.216 & 0.8287 \\
\hline The number of female & $2.54 \mathrm{E}-02$ & $6.32 \mathrm{E}-02$ & 0.402 & 0.6878 \\
\hline Electric consumption & $1.83 \mathrm{E}-03$ & $3.86 \mathrm{E}-04$ & $4.753^{* * *}$ & $2.01 \mathrm{E}-06$ \\
\hline Concrete house & $1.20 \mathrm{E}+01$ & $5.35 \mathrm{E}+02$ & 0.022 & 0.9821 \\
\hline Wooden house & $1.17 \mathrm{E}+01$ & $5.35 \mathrm{E}+02$ & 0.022 & 0.9825 \\
\hline Mixed house & $1.18 \mathrm{E}+01$ & $5.34 \mathrm{E}+02$ & 0.022 & 0.9824 \\
\hline Hadsaifong district & $-2.14 \mathrm{E}-01$ & $3.68 \mathrm{E}-01$ & -0.583 & 0.5599 \\
\hline Saysettha district & 2.84E-01 & 3.35E-01 & 0.85 & 0.3955 \\
\hline Sikhotabong district & 3.67E-02 & $3.50 \mathrm{E}-01$ & 0.105 & 0.9164 \\
\hline Sisatthanak district & $-3.50 \mathrm{E}-03$ & 3.63E-01 & -0.01 & 0.9923 \\
\hline
\end{tabular}

\section{DISCUSSION}

As we mentioned in the RESULT part, the diffusion rate of refrigerators is over $94 \%$. It means refrigerators are widely installed in most households in Vientiane city and it is no wonder the possession of refrigerators is not significantly affected by any independent variables. It is also means the impact of EES\&L will be highly promising. 
According to this paper's co-author Phrakonkham, who lives in Vientiane city, most of energy efficiency labels on the refrigerators that have already diffused are forged. He also said one could import the labels from Thailand without refrigerators itself. This country has to immediately take corrective actions in such a situation.

The tendency of $P$-value relating to district about possession of air-conditioners depends on the types (Split wall type or Split floor type). The possession of air-conditioners (Split wall type) is significantly contributed by Monthly income and Electric consumption. On the other hand, these independent variables do not contribute for the possession of Split floor type air-conditioners. The possession of air-conditioners (Split wall type) is significantly contributed by Sisatthanak district. On the other hand, Split floor type is significantly contributed by Saysettha district. Actually, the diffusion rate is obviously different between these types; Split wall type is installed in 50\% of the households and Split floor type is installed only in $7 \%$ of households. It means that most air conditioners (Split floor type) are installed in Saysettha district.

About the possession of TVs, the contribution of monthly income and electric consumption to possession of TVs (LCD/LED) is stronger than TVs (CRT). Even though TVs (CRT) is widely installed in Vientiane, the number of shipments will decrease in future. The country should lead to replace such high consuming appliances with other type of TVs (LCD/LED or plasma).

Vacuum machines and PCs are common type of appliances. These possessions are contributed by electric consumption but not by monthly income. We can assume from this result that these appliances are diffused regardless of income level and are highly consuming electric appliances.

In general, it is reasonable to implement EES\&L policy for appliances that have high-energy efficiency potential, although it depends on the situation of the country or city. Population growth induces economic growth. Economic growth induces population growth. If the country or city will have high population in the near future, it is reasonable to focus on the appliances that have significant contribution from population. If the country will have high economic growth in the near future, it is reasonable focus on the other appliances, air-conditioners (Split wall) and CFLs.

\section{CONCLUSIONS}

Lao PDR is expected to achieve high economic growth and an increase in population. If the country introduces EES\&L, it will need data from the demand side, especially about the possession of electric appliances. In this research, we collected these data from Vientiane City and identified some variables that significantly contribute to the possession rate.

We conducted an interview survey on 600 households in Vientiane City, and then we succeeded to collect 577 households' data. We used logistic regression analysis to identify independent variables that significantly contribute to the possession of each appliance.

From the results of our analysis, we identified that the the electric consuming are the principal independent variables and the relationship of these variables with possession rates depends on appliances. And we discussed the model for diffusion of appliances in Vientiane City. Based on the recognition that Lao PDR should implement EES\&L as soon as possible alongside rapid economic growth, we contributed to the implication as to which appliances should be prioritized for implementation of EES\&L. Because of the limitation of the research, there is still a lot of room for future studies. In the future, we will implement more specific analysis using the data, and present these results and implications to the government of Lao PDR. Ideally, not only the residential sector but 
also the commercial sector should be considered and surveyed to identify the effective appliances for implementation of EES\&L in the whole of Lao PDR in the future.

\section{ACKNOWLEDGEMENT}

This research was supported by the ERIA (Economic Research Institute for ASEAN and East Asia). The project name was "Energy Efficiency Roadmap Formulation in East Asia" for ERIA Research Project on "Analysis of Energy Saving Potential in East Asia".

\section{REFERENCES}

1. McNeil, M. A., Global Potential of Energy Efficiency Standards and Labeling Programs, Lawrence Berkeley National Laboratory, 2008, http://dx.doi.org/10.2172/935754

2. CLASP, Energy Efficiency Labeling Programs aim to Shift Markets for Energy-using Products toward Improved Energy Efficiency, http://www.clasponline.org/en/WhatWeDo/EnergyEfficiencyLabeling.asp, [Accessed: 01-May-2013]

3. Energy Charter Secretariat, Policies that Work: Introducing Energy Efficiency Standards and Labels for Appliances and Equipment, ISBN: 978-905948-081-0, 2009.

4. Wiel, S., \& McMahon, J. E., Energy-efficiency Labels and Standards: A Guidebook for Appliances, Equipment, and Lighting, Lawrence Berkeley National Laboratory, 2005.

5. Rosenquist, G., et al., Energy Efficiency Standards for Equipment: Additional Opportunities in the Residential and Commercial Sectors, Energy Policy, Vol. 34, No. 17, pp 3257-3267, 2006, http://dx.doi.org/10.1016/j.enpol.2005.06.026

6. de Melo, C. A., \& Jannuzzi, G. M., Energy Efficiency Standards for Refrigerators in Brazil: A Methodology for Impact evaluation, Energy Policy,Vol. 38, No. 11, pp 6545-6550, 2010, http://dx.doi.org/10.1016/j.enpol.2010.07.032

7. Murakami, S., et al., Energy Consumption, Efficiency, Conservation, and Greenhouse Gas Mitigation in Japan's Building Sector, Lawrence Berkeley National Laboratory, 2006.

8. Lee, S-K.,, MEPS Experience in Korea, Lessons Learned in Asia: Regional Conference on Energy Efficiency Standards and Labeling, Bangkok, 2001

9. Fridley, D., et al., Impacts of China's Current Appliance Standards and Labeling Program to 2020, Lawrence Berkeley National Laboratory, 2007, http://dx.doi.org/10.2172/920173

10. Department of Electricity, Ministry of Energy and Mines in Lao PDR, ELECTRICITY STATISTICS YEARBOOK OF LAO PDR, 2010.

11. Sasaki, H., et al. Energy Efficiency Road Mapping in Three Future Scenarios for Lao PDR, Journal of Sustainable Development of Energy, Water and Environment Systems, Vol.1, No. 3, pp 172-186, 2013, http://dx.doi.org/10.13044/j.sdewes.2013.01.0013

12. McNeil, M. A., \& Letschert, V. E., Modeling diffusion of Electrical Appliances in the Residential Sector, Energy and Buildings, Vol. 42, No. 6, pp 783-790, 2010, http://dx.doi.org/10.1016/j.enbuild.2009.11.015 